\title{
A Review of Life Lessons Learnt Amidst Coronavirus Disease (Covid-19)
}

\author{
SheetalMotwani \\ MEDICAL INTERN, JAWAHARLAL NEHRU MEDICAL COLLEGE (JNMC),DATTA MEGHE \\ INSTITUTE OF MEDICAL SCIENCE (DEEMED TO BE UNIVERSITY).SAWANGI (MEGHE) \\ EMAIL ID: sheetal.motwani24100@gmail.com
}

\begin{abstract}
BACKGROUND: It is said that when things take a turn for the worse they try to teach us a lesson. What can be a better example than the ongoing series of events about SARS COV-2, the Novel Corona virus. History is observing a new lesson for Human lifetime, a very strange pandemic andits fight with a microscopic enemy.

SUMMARY: The Coronavirus outbreak was first reported on 17 Nov 2019 in the city of Wuhan in china and was declared a pandemic by the WORLD HEATH ORGANIZATION on February 11, 2020. The response from countries have been different at different levels. The virus threw us into an introspective loop, coerced us to look at the things that really matter in life, a jolt that actual life isn't all about 9-5 work and constant hustle where you are lost into the rat race. It has taught us to be prepared for the challenges in life. Like the saying goes "a lesson learned the hard way is the lesson learned for a lifetime".

CONCLUSION:The COVID-19 pandemic has brought devastating health and social consequences. But it has delivered a chance to learn valuable moral lessons that could benefit all of humanity.
\end{abstract}

KEYWORDS: Pandemic, COVID-19, lifestyle changes

\section{INTRODUCTION}

The mega pandemic 'COVID-19' has flipped our lives upside down and changed not just the way we live but also the way we introspect and behave. The shutdown is inevitable. We live in a world that is never at rest. We are constantly under pressure to be productive. Life is made up of all kinds of non-sensical things we have to deal with and now it seems worse. The last year has been different for all of us. Globally people are requested to stay at home and to accept social distancing as a part of their lifestyleto reduce the risk of spread of infection. One must protect, adapt, Engage and prepare to focus in such a critical time. Everyone has learnt to work well under stress which has made us even more resilient towards life. There's a very thin line between positive and negative views of anything. It all depends on our perspective. COVID-19 has taught us numerous life lessons to prepare us for our future together.
For every low, there's a high and it's true that even this current scenario has a silver lining to it. [1]

\section{A. GENERAL ENLIGHTENMENT}

Apart from all the negative outcomes of the coronavirus pandemic. These are a few important life lessons that we have learned so far:

1. Taking care of ourselves.

Making your happiness a priority is necessary. It is very essential to have a healthy relationship with oneself as it produces feelings and boosts your confidence and Self-esteem. Lesser selfcare can also lead to all sorts of health disorders as depression, anxiety and what not.

2. Importance of social awarenessas the global threat of coronavirus continues to emerge, its critical to improve the social awareness of the targeted Members especially the less educated ones in order to improve the overall health and wellbeing. Social Awareness plays a vital role in development and growth as society plays a really important role in this era. 
3. Taking a sick leave could save so many lives. "STAY HOME, SAVE LIVES"

The covid-19 pandemic has drastically affected the World directly and indirectly in so many ways. If youfeel sick just taking a leave could save many lives because your immune system might take it easily you never know about the other person so we've learned to stay indoors not just for ourselves but for the welfare of the society.

4. Internet facility should be a human right. The COVID-19 pandemic has shown us clearly that the internet is no longer a luxury or choice, A Convenient chance for those who can't afford it.Internet is just more of a basic necessity. It helps usto understand facts and figures, information and Knowledge for personal social and economic Development.

5. We must appreciate nature. It is all around us and yet we do not appreciate it in the daily hustle. The corona pandemic gave us Time to fall in love with Mother Nature. With people social distancing and staying indoors, theNature and wildlife just got better and better. It helps us to boost our mental health just by Looking at our beautiful earth.

6. Life comes with its ups and downs. The unpredictability of life sucks. One minute you are out eating and the next minute you are on a video call telling the world about your meal. The pandemic has just helped us realize what is actually important in life. 'Life is not going my way'. Well, that's how it's supposed to be.

7. be grateful for what you have. The virus made us understand the importance of Life and death. Life is a blessing but death is the Final destination. Gratitude unlocks the fullness of Life. It turns what we have into more than we'd, ItTurns the denial into acceptance and confusion to Clarity, all we can do is be kind to others and grateful to God that we are alive for good.

With over 1.2 million lives lost to the pandemic has made me re-think everything and remember how precious all of us really are. Our number one priority should be strengthening our health-care systems and to create security nets for economically vulnerable segments of society. After being alone most of the time amidst pandemic we have realized the importance of empathy and kindness therefore we must use social and emotional learning. It will be the best step for a sustainable and peaceful place. Good things take time and COVID-19 is giving us that time to set our priorities right. The outbreak is just a reminder to not take things for granted. Everything doesn't have to be perfect in life for us to be really happy and to appreciate ourselves and everything around us. Everybody makes mistakes and we must normalize accepting ourselves. Nowadays, everyone tends to be hard on themselves and that's just the worst thing to do because it won't take you anywhere. Learn to love, to listen, to care, to respect and to help.

\section{B. SHUFFLING OF PRIORITIES}

The pandemic has endangered a spiritual quest and an inner peace disposition. Most of us realize the significance of the happiness and peace within. We have a deep innate necessity to be around people to socialize and share our lives. People who are connected tend to be happier and healthier in life. As everyone is quarantined at home, the lockdown has given us the opportunity to go back to the days when family time was the most important be it mealtime, Household works, Board games and what not. All of this just helps in being more and more empathetic. It even becomes impossible to be in touch with all the people involved in your life, now we do have the time to reconnect with our friends and family. We need to remember how important kindness is. We have learnt that we don't really need to spend the amount we usually do which has helped to reset our priorities from money to more important things like Inner peace, Family and things which help 
us for our personal growth and development in the longer run. Our medical capacities are limited but we have huge reserve capacity, which has helped us a lot to fight against the serious outbreak of this virus. We are actually beyond our earth's boundaries. It's not crazy to expect that we will find solutions that will provide the wellbeing of the economy and ecology.

\section{THE WORLD IS WILDLY INTERCONNECTED}

We love to remember this when it helps us talking about the connectivity that technology allows. But we are obviously all connected, as evidenced by the enormous spread of the coronavirus around the planet. To think that we are all the same is just flawless. Once we adapt that, we'll be probably be better off both internally and externally for future pandemic. Our world economy is now really interconnected by supply and communication chains just as we use the same stuff, see the same things we are suffering from the same disease. Everything must go somewhere the pandemic shouldn't go for waste, it has shown us how we are so much related to each other.

Globalization is not going away as security remain the major function of government. No one is safe until everyone is safe. Interconnectedness is the only thing helping us to combat the virus emotionally and physically. We really need coordinated action by government which supports frontline workers and ensures social security in order to boost the real economy when the recovery comes. An approach is required to promote equality. The potential collapse of multimaterialism and globalization has intensified as COVID-19 pushes political isolation even further. International collaboration and exchange of resources online is equally important. Many successful digital ventures will have consequences and the internationalization of senior education will have serious setbacks. No single country can say that they are immune against the virus the issues are the same for everyone. The epidemic itself and the educational crisis can be easily solved by global cooperation and strongly refined international organizations. Despite all the differences and distance between all these Places, we all are battling the same virus, facing the same issues, the pandemic is just a reminder to understand how everything is interconnected on so many levels including communication, technology and travel. [2]

\section{ADAPTATION IS THE KEY}

Times are changing, and more change is coming. We must adapt to those life changing events and be prepared for any possibilities. The pandemic has been a time of extraordinary change and we have rapidly changed everything we had. Many people lost jobs, People started working from home, and we all turned out to be pretty flexible and creative in the face of uncertain for many. Our work and personal lives have deteriorated in every way possible. All of us must be ready to adapt and manage than before, it's truly astonishing how we changed ourselves in this situation, and adjustment and adaptation are not easy. It is certainly tough, it helped us top practice gratitude and adapt to work in heavy pressure conditions, made us realize that us humans are way above everything else because we have the ability to evolve. Moving forward, there's more difficulties in the horizon, the capacity to cope with and adapting the change when unforeseen events alter life plans define who we really are, unexpected things are bound to happen and COVID-19 has tested us in every way possible and has made us so much more flexible. The pandemic could be the apocalypse but we still try to cut the day by adapting to everything we can. We just became more mindful and more 
human as we got this rest to realize our wants and needs.

\section{E. THE HARSH REALITY HAS BEEN EXPOSED}

Every global crisis has been followed by a period of boom. [3] There is no way the economy wouldn't bounce back stronger this time around. Moreover, apart from all the economic impacts, the outbreak made us realize a lot about our health care system as well. Meanwhile isolation has become a tinsel bit more bearable if we focus on the positive side of everything. We have focused more on our needs than our Greed, we've started to be more caring and loving. The doctors and scientists have been the most underrated as they've done so much to the humanity, it strikes us bad now as these people have not got the respect and love that they really deserve because they are the ones working day and night for the recovery of our Nation. We've understood the importance of washing hands regularly as it's the most effective way to maintain regular hygiene. The most important thing is that we have been living in a bubble all this while and COVID-19 just burst it by teaching us the importance of life. We learn how to live each and every day. We choose the path we take; we learn and continue to learn. It has given us a lot of time to introspect the little things in life by devoting so much time to oneself. Everything can end in a day. We can just hope for our wellbeing and be grateful for what we have. This has been a serious time for our mental health as we humans are social creatures who need social contact, we have lived by ourselves, loved ourselves and we cannot ask for more than that.

\section{F. HOW THE WORKPLACE GOT AFFECTED}

Coronavirus has been the most traumatic experience of our lives. It will have a huge impact on us individually and our workplace as well. We understood the concept of corporate flexibility as people quickly figured out how to work from home. It has been profitable for the company and the workers. The workplace afterwards will be far more social than we could think. Our humanity and connection as the only thing differentiating us from robots. COVID-19 has made us realize the importance of such interactions. Upskilling and right-skilling are really important for innovation and creation. Ramping up Elearning has been the best thing ever as companies moved quickly to ensure that people are still developing professionally. The virus has been a catalyst to reinvent the future of work for managers to make things better than ever. We have moved forward and adapted trends such as automation and digitization. The agility has increased because people found less expensive ways to operate. Now, many companies will rebalance the priorities in a few months so that the working gets more efficient and resilience will become just as important to their strategic as cost and efficiency. People are learning how to do the work disparately with less oversight, ironically, amidst the social lockdown all of us getting closer but beyond that we are connected with purpose and as a beautiful community. There's no blueprint for our routine anymore. It is necessary that corporate and leadership skills focus on empathy as flexibility is the new normal. The economic impact has affected youth employment. Changes in workload during the pandemic has resulted in various imbalance. Ranking and upskilling can help us to get better than ever. It is very important not to focus on telework to the exclusion of millions of workers who've returned to work as they should be given better resources from the government. Issues facing long-term teleworkers are still emerging and it had psychological impacts, family challenges and inconsistencies in compliance with the laws of the workplace. [4] 
Preventing the damage being done to the human rights will be the key to maintaining trust with consumers and share-holders. It will be a key to building a world of greater strength and resilience

What really matters?

We've spent a lot of time with ourselves during this pandemic. Too often, we feel so stuck thinking about what might happen in the future. We either regret about the past or overthinking about the future, we have realized that life is not going to be predictable at all. There is only now, we must live in the moment to enjoy our own company. No one knows who they really are, so one must find their authenticity by searching themselves. Self-help loves you to help others. Don't Let anyone postpone your small and achievable goals as present is the best time to improve and achieve. Now, we know that shutdown works and hygiene helps. The most important realization we've had is that we can no longer continue with the extreme exploitation of nature. [5]

All must try and ensure that we get positive so that we do not get back to the old normal, but adapt a better normal. The whole world needs a restricting of development plans which involve at least 4\% GDP to health and education because co-operating with the society is the only option for continuing the path of success. International collaboration in crises is essential and we were too late to understand that. The virus helped us revisit our relationships to increase the love and affection. Apart from everything else, each and every person now believes in silence and solitude to explore the deeper recesses of our consciousness as the most important thing is to find that divine light within. We have understood that experiences and values matter the most. Peace, health, family, purpose, time, learning and love are the most important things in this life. What matters now is that we are alive and safe altogether. What matters now is knowing the importance of our precious lives. All we can do is to be present in this fragile moment together.

\section{LOOKING AT THE BRIGHT SIDE OF THE PANDEMIC}

Without us constantly travelling around and rushing throughout the world, the coronavirus has given us a lot to feel bad about. But on the other hand, it has its own positive impacts as well. For example-less air pollution and the return of wildlife haven't been seen for a really long time period of time. It also helped to boost our global economy. When the fund was required to recover from the extremes, many charity heroes of the nation supported the government and donated everything they could. In such tough times, our country's doctors, policeman, NGO's have been working so hard to protect the people from the virus to perform duties which has made the whole country so proud. The most notable impact has been the increase in poor people using their bank accounts. Financial inclusion has increased amid the pandemic. We have also witnessed much greater use of Information and communication technology and digitization (ICT). Increased concern has helped us to be more cautious with our surroundings. Actually it has been sort of a vindication of our public sector Moreover, the forced isolation has been a reminder of how much our loved ones mean to us genuinely. We have realized that we are equal when it comes to the force of nature. We understand how much we depend on each other. Humanity is at its best, we have experienced heightened community spirit. One of the most important things learnt amidst COVID-19 is the importance of health and hygiene which has made us better human beings. The lesser supply of all the items because of social distancing and limited supplies, the wastage of food has reduced by a large margin. Now, we have started to focus more on our mental 
and physical health. This has turned out to be such a big opportunity for the overall development as the crime rate has also decreased drastically. The major nonpermanent gains gifted by the corona pandemic:

A) Nitrogen dioxide fell by $40-50 \%$ in all the metro cities. PM (particulate matter) 2.5 and PM 10 levels too have slid. Since factories are closed and transportation is not required, India's AQI (Air Quality Index) is improving. [6]

B) Lower crime rate.

C) Increased use of PDF documents has drastically reduced the use of paper during the pandemic.

D) Increased punctuality in every way possible.

E) Enhanced family life.

F) Wild life is rejuvenating. Apart from sighting the occasional leopard on the streets of quasi-urban Maharashtra and spotting flocks of flamingos in Navi Mumbai, other wildlife including that of mountain goats, bison, wild cats, fishing cats, civets and birds. [7]

H) GDP growth rates: When there is economic gloom across the entire globe, the Indian economy is expected to expand by around $2 \%$ in 2020 as well. [8]

I) India's total e-commerce shopper base, at $30 \%$ of its online population, is quite low when compared with $78 \%$ in China and over $70 \%$ in the US. In a 53-page report on 'India's Digital Economy in a Post-Covid-19 World', Morgan Stanley has projected that India's online shoppers will jump to 590 million from 190 million in 2020 [9]

j) Break in routine and time to restructure life. It's commonly thought that time spent alone provides an opportunity to stop and reflect. With social distancing measures limiting people's lives, it is a good time to have a think about what really matters. [10]

K) The complexity of disasters will be better understood, triggering higher preparedness level [11]
The pandemic has allowed us to make decisions and implement them which were not possible in normal times. We must focus on taking the advantage of this situation to solve issues that will impact our future as overwhelming levels of informality. We must learn to add a touch of optimism to these difficult times. ) As it is very rightly said by Rahm Emanuel, "You never let a serious crisis go to waste. And what I mean by that it's an opportunity to do things you think you could not do before.'[12-13]. Many related articles are reflecting in literature [14-17]. Studies shedding light on financial, psychological, positive and negative aspects of Covid were reported[18-21].

\section{CONCLUSION}

Time only will tell how the coronavirus will affect our lives hereafter. Not everything about COVID-19 is abysmal. Like every other pandemic, this too shall pass. It's hard for people to be still and do nothing. Your mind and body just your home and you must learn how to love it and live with it. We must know how to cook by ourselves, laugh by ourselves and not feel exhausted. We should be Happy to trade some of our freedom for the greater good of the public. At the end of the day, Life won't get easier or forgiving, we will get stronger and resilient. Currently there is no documented cure for the virus and no vaccine has been created, some treatment ideas have been promising, so the virus can be controlled with the prevention strategies. Apart from curbing the outbreak, changes should be made to prevent future outbreaks of zoonotic origin.

\section{CONFLICT OF INTEREST: none} FUNDING: DMIMS 


\section{REFERENCES:}

[1] Positive Impacts of COVID-19 Pandemic (2020) SurveySparrow. Available at: https://surveysparrow.com/blog/posit ive-impacts-to-look-forward-to-postcovid-19-pandemic/ (Accessed: 3 December 2020).

[2] Khanna, R. C. et al. (2020) 'COVID19 pandemic: Lessons learned and future directions', Indian Journal of Ophthalmology, 68(5), p. 703. doi: 10.4103/ijo.IJO_843_20

[3] Triggle, C. R. et al. (2020) 'COVID19: Learning from Lessons To Guide Treatment and Prevention Interventions', mSphere, 5(3). doi: 10.1128/mSphere.00317-20

[4] OPINION: What lessons have we learned from Covid-19? | Traffic Technology Today (no date). Available at: https://www.traffictechnologytoday.c om/opinion/opinion-the-lessonstransportation-has-learned-fromcovid-19-so-far.html (Accessed: 3 December 2020).

[5] 'Eight Key Lessons to Learn from COVID-19 Pandemic' (2020) Express Healthcare, 22 April. Available at: https://www.expresshealthcare.in/blo gs/eight-key-lessons-to-learn-fromcovid-19-pandemic/419184/ (Accessed: 3 December 2020).

[6] 'COVID-19 - Its Impact On The World!' (2020) PharmEasy Blog, 14 April. Available at: https://blogprod.pharmeasy.in/blog/covid-19-itsimpact-on-the-world/ (Accessed: 3 December 2020).

[7] Kumar, V. (no date) 6 Ways TheCovid -19 Is Making A Positive Impact, $B W \quad$ Businessworld. Available at: http://businessworld.in/article/6Ways-The-Covid-19-Is-Making-A-
Positive-Impact/12-05-2020-191781 (Accessed: 3 December 2020).

[8] 'Positive Side of COVID Impact on Economy: Especially for India' (2020) Insights Success, 11 May. Available at: https://www.insightssuccess.in/positi ve-side-of-covid-impact-oneconomy-especially-for-india/ (Accessed: 3 December 2020).

[9] Long term positive economic effects of coronavirus (no date). Available at:

https://www.indiainfoline.com/article /general-blog/5-long-term-positiveeconomic-effects-of-coronavirus120072400471_1.html (Accessed: 3 December 2020).

[10] Ten good things to come out of the coronavirus pandemic (2020) Al Arabiya English. Available at: https://english.alarabiya.net/en/coron avirus/2020/05/04/Ten-good-thingsto-come-out-of-the-coronaviruspandemic (Accessed: 3 December 2020).

[11] Sharma, D. A. (2020) The Good, The Bad and The Ugly: Six long lasting impacts of Covid19, YourStory.com. Available at: https://yourstory.com/2020/05/goodbad-ugly-long-lasting-impacts-covid19 (Accessed: 3 December 2020).

[12] Srivastava, R. (2020) Positive Effects of Coronavirus (COVID-19) In Our Lives, YourStory.com. Available at: https://yourstory.com/mystory/positi ve-effects-coronavirus-lives (Accessed: 3 December 2020).

[13] Gavi, the Vaccine Alliance (no date). Available at: https://www.gavi.org/ (Accessed: 3 December 2020).

[14] Chaudhari, B.V., and P.P. Chawle. "Life Lessons of the Pandemic "COVID-19"." International Journal of Research in Pharmaceutical Sciences 11, no. Special Issue 1 (2020): 469-71. 
https://doi.org/10.26452/ijrps.v11iSP L1.2814.

[15] Patil, D., and W.M. Naqvi. "COVID19 and Education System: Impact of Current Pandemic on Adaptive Learning Strategies in Medical Education System." International Journal of Research in Pharmaceutical Sciences 11, no. Special Issue 1 (2020): 403-6. https://doi.org/10.26452/ijrps.v11iSP L1.2736.

[16] RathiSaurabh, D., P. Nikhade, N. Motwani, S. Baror, and A. Jaiswal. "Coronavirus Pandemic-the Real Lessons Are Learnt in the Time of Crises." International Journal of Research in Pharmaceutical Sciences 11, no. Special Issue 1 (2020): 101114.

https://doi.org/10.26452/ijrps.v11iSP L1.3426.

[17] Adhit, K.K., P. Anjankar Ashish, and K. Siddhaarth. "COVID-19: A Review of Its Clinical Features, Effects on Gastrointestinal System and Possibility of Faecal Transmission." International Journal of Research in Pharmaceutical Sciences 11, no. Special Issue 1 (2020): 623-27. https://doi.org/10.26452/ijrps.v11iSP L1.2881.

[18] Agrawal, D., N. Khara, B. Mundada, N. Bhola, and R. Borle. "COVID-19 and Its Financial Effects on the Dental Fraternity and Health-Care Workers: A Literature Review." International Journal of Research in Pharmaceutical Sciences 11, no. Special Issue 1 (2020): 628-31. https://doi.org/10.26452/ijrps.v11iSP L1.2883.

[19] Bakshi, S., V. Toshniwal, A. Agrawal, S. Acharya, and S. Shukla. "Awareness and Psychosocial Effects of Covid-19 Pandemic on Health Care Professionals and Medical Students across the State of
Maharashtra." International Journal of Current Research and Review 12, no. 22 Special Issue (2020): S-122-S125 .

https://doi.org/10.31782/IJCRR.2020 .SP74.

[20] Borage, S., and P. Shelotkar. "Positive Effects of Covid-19 on Earth." International Journal of Research in Pharmaceutical Sciences 11, no. Special Issue 1 (2020): 23438 .

https://doi.org/10.26452/ijrps.v11iSP L1.2704.

[21] Kamdi, P.S., and M.S. Deogade. "The Hidden Positive Effects of Covid-19 Pandemic." International Journal of Research in Pharmaceutical Sciences 11, no. Special Issue 1 (2020): 276-79. https://doi.org/10.26452/ijrps.v11iSP L1.2712. 